\title{
Islet adaptations in fetal sheep persist following chronic exposure to high norepinephrine
}

\author{
Xiaochuan Chen 1,2, Amy C Kelly2, Dustin T Yates², Antoni R Macko², Ronald M Lynch³ \\ and Sean W Limesand ${ }^{2}$
}

${ }^{1}$ Chongqing Key Laboratory of Forage \& Herbivore, College of Animal Science and Technology, Southwest University, Chongqing, China

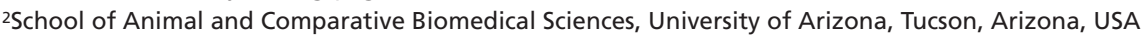

${ }^{3}$ Department of Physiology, University of Arizona, Tucson, Arizona, USA

Correspondence should be addressed to S W Limesand

Email

limesand@email.arizona.edu

\begin{abstract}
Complications in pregnancy elevate fetal norepinephrine (NE) concentrations. Previous studies in NE-infused sheep fetuses revealed that sustained exposure to high NE resulted in lower expression of $\alpha_{2}$-adrenergic receptors in islets and increased insulin secretion responsiveness after acutely terminating the NE infusion. In this study, we determined if the compensatory increase in insulin secretion after chronic elevation of NE is independent of hyperglycemia in sheep fetuses and whether it is persistent in conjunction with islet desensitization to NE. After an initial assessment of glucosestimulated insulin secretion (GSIS) at $129 \pm 1$ days of gestation, fetuses were continuously infused for seven days with NE and maintained at euglycemia with a maternal insulin infusion. Fetal GSIS studies were performed again on days 8 and 12. Adrenergic sensitivity was determined in pancreatic islets collected at day 12. NE infusion increased $(P<0.01)$ fetal plasma NE concentrations and lowered $(P<0.01)$ basal insulin concentrations compared to vehicle-infused controls. GSIS was 1.8 -fold greater $(P<0.05)$ in NE-infused fetuses compared to controls at both one and five days after discontinuing the infusion. Glucose-potentiated arginine-induced insulin secretion was also enhanced $(P<0.01)$ in NE-infused fetuses. Maximum GSIS in islets isolated from NE-infused fetuses was 1.6-fold greater $(P<0.05)$ than controls, but islet insulin content and intracellular calcium signaling were not different between treatments. The half-maximal inhibitory concentration for NE was 2.6 -fold greater $(P<0.05)$ in NE-infused islets compared to controls. These findings show that chronic NE exposure and not hyperglycemia produce persistent adaptations in pancreatic islets that augment $\beta$-cell responsiveness in part through decreased adrenergic sensitivity.
\end{abstract}

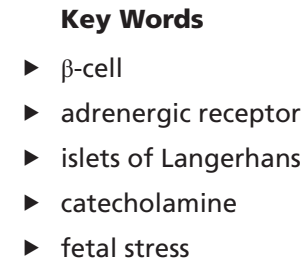

Journal of Endocrinology (2017) 232, 285-295

\section{Introduction}

Fetal stress imposed by complications such as ischemic placental disease leads to prolonged increases in fetal circulating catecholamines (Greenough et al. 1990, Okamura et al. 1990, Ananth \& Vintzileos 2006,
Ananth \& Friedman 2014). Elevated epinephrine and norepinephrine (NE) concentrations in the fetus are primary determinants for adaptive changes in metabolism and reduced growth rates (Apatu \& Barnes 1991, 
Milley 1997, Bassett \& Hanson 1998, Davis et al. 2015). Catecholamines suppress insulin release via $\alpha_{2}$ adrenergic receptors ( $\alpha_{2}$-ARs) on pancreatic $\beta$-cells (Sperling et al. 1984, Jackson et al. 2000, Yates et al. 2012a). In an ovine model of placental insufficiency-induced intrauterine growth restriction (PI-IUGR), glucose-stimulated insulin secretion (GSIS) was attenuated, in part, by elevated catecholamine concentrations (Limesand et al. 2006, Macko et al. 2016). Pharmacological adrenergic blockade in IUGR sheep fetuses ameliorated the deficiency in GSIS, even though $\beta$-cell mass was substantially lower (Leos et al. 2010, Macko et al. 2013, Limesand et al. 2013). To define the islet response to chronic adrenergic stimulation during gestation, we infused NE into normal sheep fetuses for seven days and showed that continuous exposure to high NE concentrations suppressed fetal insulin secretion and raised fetal glucose concentrations. Moreover, three hours after terminating the chronic NE infusion, we observed an enhancement in insulin secretion responsiveness to glucose and arginine challenges (Chen et al. 2014). Expression levels of $\alpha_{2}$-AR and $\mathrm{G} \alpha_{\mathrm{i}-2}$ protein were also reduced in islets from this cohort of NE fetuses (Chen et al. 2014). Our findings from these two distinct models of chronic hypercatecholaminemia, PI-IUGR and NE infusion indicate that sustained adrenergic stimulation produces a compensatory augmentation in $\beta$-cell responsiveness. Therefore, we propose that NE-induced adaptations in fetal islets may produce a discord between insulin secretion and insulin action during the transition from fetal to postnatal life and predispose offspring to metabolic complications.

In this study, we test the hypothesis that the compensatory increase in insulin secretion responsiveness and adrenergic receptor desensitization in islets persist in sheep fetuses after a period of chronic hypercatecholaminemia and are not dependent upon fetal hyperglycemia. In our previous work, glucose concentrations were incongruent between IUGRand NE-infused fetuses and both hypoglycemia and hyperglycemia negatively affect $\beta$-cell responsiveness (Carver et al. 1995, Green et al. 2012, Chen et al. 2014, Macko et al. 2016). To avoid confounding results from glucose, we maintained euglycemic conditions in the fetus during the NE infusion with a simultaneous maternal infusion of insulin. We show that the compensatory increase in insulin secretion responsiveness to glucose and arginine stimulation was present five days after discontinuing the NE treatment. Furthermore, isolated islets from the NE fetuses exhibited greater GSIS and NE desensitization.

\section{Materials and methods}

\section{Animal preparation}

Studies were conducted in 15 pregnant ColumbiaRambouillet crossbred ewes carrying a singleton fetus (Nebeker Ranch, Lancaster, CA, USA). Ewes were fed Standard-Bread Alfalfa Pellets (Sacate Pellet Mills, AZ, USA) and provided water and salt ad libitum. Indwelling vascular catheters were surgically placed into ewes and fetuses for arterial blood sampling and intravenous infusions at $123 \pm 1$-day gestational age (dGA). Animal husbandry was performed as previously reported (Chen et al. 2014, Macko et al. 2016). All animal procedures were approved by the Institutional Animal Care and Use Committee and performed at the University of Arizona, which is accredited by the American Association for Accreditation of Laboratory Animal Care.

\section{Experimental treatments}

Sheep fetuses were randomly assigned to control $(n=7)$ or $\mathrm{NE}(n=8)$ groups at $129 \pm 1 \mathrm{dGA}$. Control fetuses received an infusion of diluent $(0.3 \%$ ascorbic acid in $0.9 \%$ saline), and ewes received an infusion of diluent $(0.9 \%$ saline with $0.5 \% \mathrm{BSA}$ ). NE fetuses received an infusion of NE (Norepinephrine Bitartrate, Bedford Laboratories, $\mathrm{OH}, \mathrm{USA} ; 1-4 \mu \mathrm{g} / \mathrm{min}$; IV) for 7 days at preset rates for each day of treatment (day 1 at $1 \mu \mathrm{g} / \mathrm{min}$, days $2-4$ at $2 \mu \mathrm{g} / \mathrm{min}$ and days 5-7 at $4 \mu \mathrm{g} / \mathrm{min}$; Chen et al. 2014). Insulin (Humulin R; Eli Lilly; 30-60 pmol/min/ $\mathrm{kg}$ ) was intravenously infused into ewes to maintain euglycemic conditions in fetuses during NE infusion (Limesand \& Hay 2003, Rozance et al. 2006). The rates of NE infusion were previously shown to recapitulate physiological concentrations observed in response to fetal hypoxemia in human and sheep (Greenough et al. 1990, Yates et al. 2012a, Chen et al. 2014). All infusions were terminated on day 7 of treatment, $24 \mathrm{~h}$ prior to the second GSIS study.

\section{Experimental design and insulin secretion studies}

Three GSIS studies were performed before (GSIS-pre), 1 day after (GSIS-1d) and 5 days after (GSIS-5d) the chronic infusion in all but one control fetus, where the final GSIS study was lost due to loss of catheter patency. The GSIS studies were conducted as described previously (Limesand et al. 2006, Leos et al. 2010). Briefly, a continuous transfusion of maternal arterial blood into the fetus $(10 \mathrm{~mL} / \mathrm{h})$ was started $30 \mathrm{~min}$ prior

Published by Bioscientifica Ltd 
to sampling and maintained for the duration of the study to compensate for blood collection. Three baseline blood samples were collected within the 20 min preceding the dextrose bolus at 5- to 7-min intervals. The square-wave hyperglycemic clamp was initiated with a dextrose bolus of $1.19 \pm 0.04 \mathrm{mmol} / \mathrm{kg}$ estimated fetal weight followed by a constant infusion of 33\% dextrose to increase and maintain fetal arterial plasma glucose concentration at $2.5 \pm 0.1 \mathrm{mmol} / \mathrm{L}$, which produces a near-maximal GSIS response (Green et al. 2011). During the hyperglycemic clamp, three fetal arterial plasma samples were collected at 45,50 and $55 \mathrm{~min}$ during steady-state conditions when concentrations varied less than $\pm 6 \%$ of the mean and showed no systematic trend with time. Averages for baseline and hyperglycemia steady state periods were calculated for comparisons. Maximal insulin secretion responsiveness was measured with a follow-on arginine bolus $(0.5 \mathrm{mmol} / \mathrm{kg}$ estimated fetal weight $)$ as described previously (Gresores et al. 1997, Green et al. 2012).

\section{Biochemical analysis}

Fetal arterial blood samples were collected and prepared for analysis as described previously (Chen et al. 2014). Fetal blood samples were collected for blood gasses, $\mathrm{pH}$ and oximetry measurements with an ABL 725 (temperature corrected to $39.1^{\circ} \mathrm{C}$; Radiometer, Copenhagen, Denmark). Plasma glucose and lactate concentrations were measured immediately with an YSI model 2700 SELECT Biochemistry Analyzer (Yellow Springs Instruments, Yellow Springs, OH, USA). Plasma samples for insulin and $\mathrm{NE}$ measurements were stored at $-80^{\circ} \mathrm{C}$. Insulin concentrations were measured with an ovine insulin ELISA (ALPCO Diagnostics, Windham, NH, USA) that had a $9.1 \%$ inter-assay and $8.5 \%$ intra-assay coefficients of variation. NE concentrations were measured by noradrenaline ELISA (Labor Diagnostika Nord GmbH \& Co.KG, Nordhorn, Germany) that had a $22.5 \%$ inter-assay and $19.6 \%$ intra-assay coefficients of variation.

\section{Necropsy and islet isolation}

After GSIS-5d, animals were recovered for $3-5 \mathrm{~h}$ before ewes and fetuses were killed with an overdose of sodium pentobarbital $(86 \mathrm{mg} / \mathrm{kg})$ and phenytoin sodium $(11 \mathrm{mg} / \mathrm{kg}$, Euthasol; Virbac Animal Health, Fort Worth, TX, USA). Fetuses and fetal organs were dissected and weighed. The hepatic portion of pancreas was collected for islet isolation (Limesand et al. 2006). The splenic
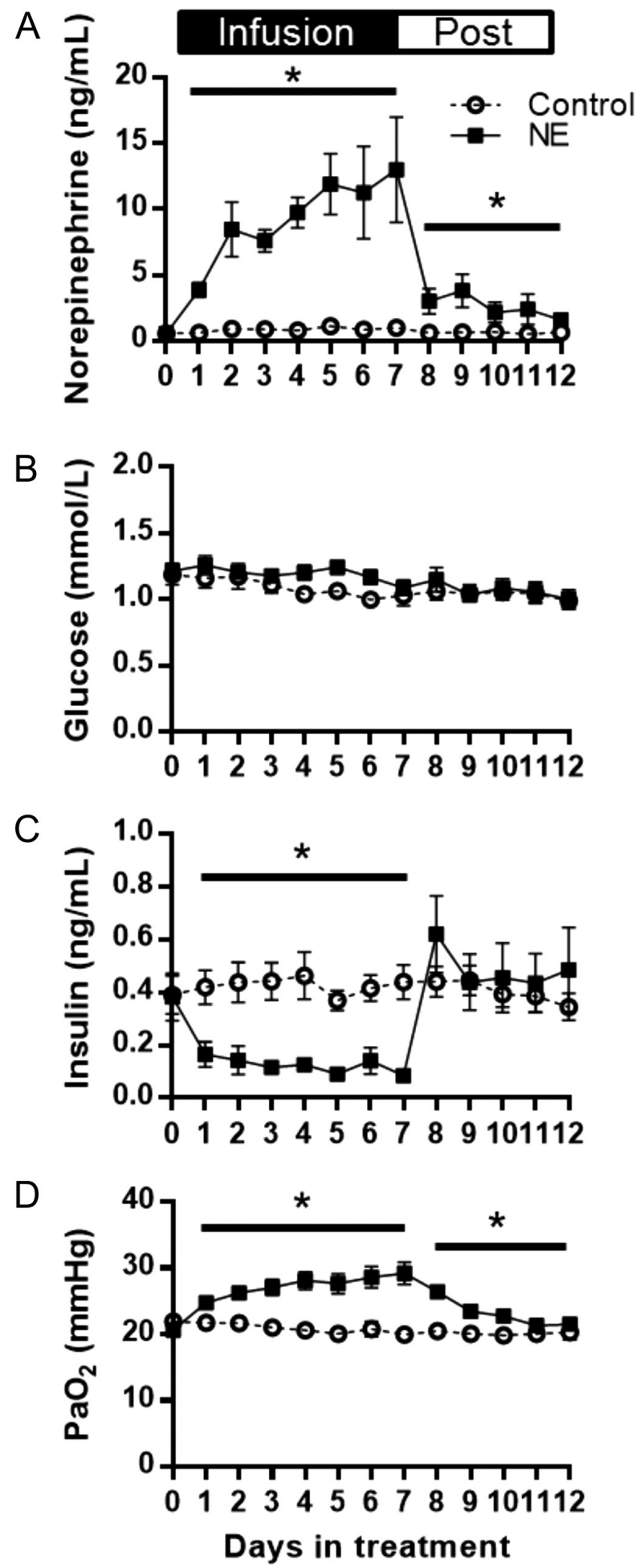

Figure 1

NE infusion inhibits insulin concentrations. Daily arterial means are presented for control (circles, $n=7$ ) and NE fetuses (squares, $n=8$ ). Values for plasma norepinephrine (A), plasma glucose (B), plasma insulin (C) and partial pressure of blood oxygen $\left(\mathrm{PaO}_{2}, \mathrm{D}\right)$ were determined for each day of treatment $(x$-axis). Difference $(P<0.05)$ during the infusion and post-infusion periods is identified with an asterisk. 
portion of pancreas was fixed in $4 \%$ paraformaldehyde overnight and prepared for histological analysis as described previously (Cole et al. 2009).

Islets were isolated after the fetal pancreas was digested in Krebs-Ringer Buffer (KRB) with Collagenase V $(0.425 \mathrm{mg} / \mathrm{mL}$; Sigma $)$ and DNase I $(2 \mu \mathrm{U} / \mathrm{mL}$; Roche Diagnostics) as described previously (Limesand et al. 2006, Chen et al. 2014, Rozance et al. 2015). Isolated islets were washed in KRB containing 0.5\% BSA (KRB-BSA). Islets were cultured overnight in RPMI-1640 medium (Sigma-Aldrich) supplemented with $2 \%$ fetal bovine serum, $2.8 \mathrm{mmol} / \mathrm{L}$ glucose and penicillin-streptomycin (50 U and $50 \mathrm{mg}$; SigmaAldrich) at $37^{\circ} \mathrm{C}$ with $95 \% \mathrm{O}_{2}-5 \% \mathrm{CO}_{2}$ (Limesand et al. 2006, Green et al. 2012).

\section{Islet static incubations}

Fetal islets from control $(n=6)$ and NE fetuses $(n=6)$ were washed twice in KRB-BSA and a third time in KRBBSA supplemented with $10 \mu \mathrm{mol} / \mathrm{L}$ forskolin (SigmaAldrich). All media was equilibrated to $37^{\circ} \mathrm{C}$ and gassed with $95 \% \mathrm{O}_{2}-5 \% \mathrm{CO}_{2}$. Ten islets were handpicked (3-4 replicates/condition for each fetus) and incubated at $37^{\circ} \mathrm{C}$ in $1 \mathrm{~mL}$ KRB-BSA-forskolin media with high $(11.1 \mathrm{mmol} / \mathrm{L})$ and no $(0 \mathrm{mmol} / \mathrm{L})$ glucose, high glucose plus NE $(0.1 \mathrm{nmol} / \mathrm{L}-10 \mu \mathrm{mol} / \mathrm{L})$ and $1.1 \mathrm{mmol} / \mathrm{L}$ glucose plus $30 \mathrm{mmol} / \mathrm{L} \mathrm{KCl}$. After a 1-h static incubation, islets were pelleted by centrifugation $(800 \mathrm{~g})$ at $4^{\circ} \mathrm{C}$ for $3 \mathrm{~min}$. The media was removed and insulin was extracted from islets with acid ethanol (1 $\mathrm{M} \mathrm{HCl}$ in $70 \%$ ethanol) to determine the islet insulin content. The effectiveness of $\mathrm{NE}$ in inhibiting insulin secretion was determined by the half-maximal inhibitory concentration $\left(\mathrm{IC}_{50}\right)$ using the dose response equation (log (inhibitor) vs normalized response; Prism 6, GraphPad Software).

\section{Whole-islet calcium dynamics}

Islets were incubated overnight on glass coverslips precoated with human fibronectin $(10 \mathrm{mg} / \mathrm{L}$ in PBS; BD Biosciences, Bedford, MA, USA (Green et al. 2011)). Islets from control and NE fetuses ( $n=3 /$ treatment) were washed at $4^{\circ} \mathrm{C}$ for $10 \mathrm{~min}$ with glucose-free Hank's Balanced Salt Solution (HBSS; $5 \mathrm{mmol} / \mathrm{L} \mathrm{KCl}, 0.3 \mathrm{mmol} / \mathrm{L} \quad \mathrm{KH}_{2} \mathrm{PO}_{4}$, $138 \mathrm{mmol} / \mathrm{L} \quad \mathrm{NaCl}, \quad 0.2 \mathrm{mmol} / \mathrm{L} \quad \mathrm{NaHCO}_{3}, \quad 0.3 \mathrm{mmol} / \mathrm{L}$ $\mathrm{Na}_{2} \mathrm{HPO}_{4}, 20 \mathrm{mmol} / \mathrm{L}$ HEPES, $1.3 \mathrm{mmol} / \mathrm{L} \mathrm{CaCl}_{2}$ and $0.4 \mathrm{mmol} / \mathrm{L} \mathrm{MSO}_{4}, \mathrm{pH} 7.4$ ) and then loaded with fura-2 acetoxymethylester $(2.5 \mu \mathrm{mol} / \mathrm{L} ; \quad$ Molecular Probes $)$ in glucose-free HBSS with $0.0025 \%$ pluronic acid for $20 \mathrm{~min}$ at $4^{\circ} \mathrm{C}$ and $20 \mathrm{~min}$ at $25^{\circ} \mathrm{C}$. The islets were rinsed, incubated in HBSS with $1.1 \mathrm{mmol} / \mathrm{L}$ glucose for $10 \mathrm{~min}$ at $37^{\circ} \mathrm{C}$ and mounted onto the stage of an Olympus IX-70 microscope. Fura- 2 was alternately excited at 340 and $380 \mathrm{~nm}$ and emitted light $(508 \mathrm{~nm})$ was captured on a Photometrics $\mathrm{CH} 250$ camera as described previously (Lynch et al. 2008). Images were acquired at 0.5- to 1-min intervals in the following series of media conditions: low glucose $(1.1 \mathrm{mmol} / \mathrm{L})$ for $5 \mathrm{~min}$; high glucose $(11.1 \mathrm{mmol} / \mathrm{L})$ for $20 \mathrm{~min} ; 30 \mathrm{mmol} / \mathrm{L} \mathrm{KCl}$ for $5 \mathrm{~min}$ and $10 \mu \mathrm{mol} / \mathrm{L}$ ionomycin for $4 \mathrm{~min}$. Data were analyzed for 25-67 fields of view obtained from 2 to 6 islets per fetus (coefficient of variation between islets $=6.1 \%$ ).

\section{Histology of fetal pancreatic endocrine cells}

Pancreatic tissue sections $(6 \mu \mathrm{m})$ were cut from frozen OCT-embedded control $(n=7)$ and NE $(n=6)$ fetuses and prepared for histological evaluation as described previously (Cole et al. 2009, Leos et al. 2010). Endocrine cells were identified with guinea pig anti-porcine insulin (1:500; Dako), mouse anti-porcine glucagon (1:500; Sigma-Aldrich), rabbit anti-human somatostatin (1:500; Dako) and rabbit anti-human pancreatic
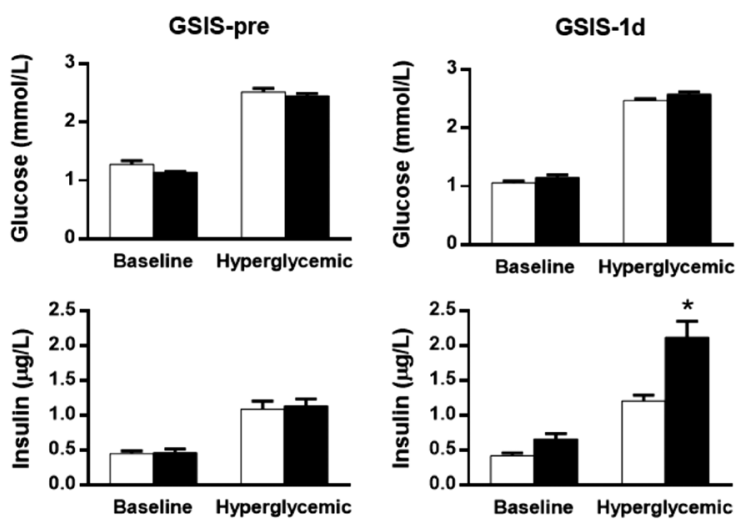

GSIS-1d

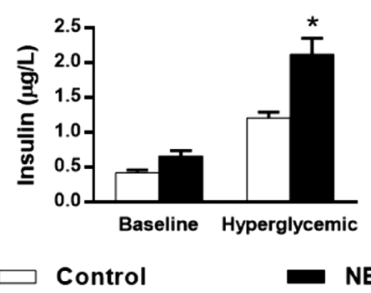

(C) 2017 Society for Endocrinology Printed in Great Britain http://joe.endocrinology-journals.org DOI: 10.1530/JOE-16-0445

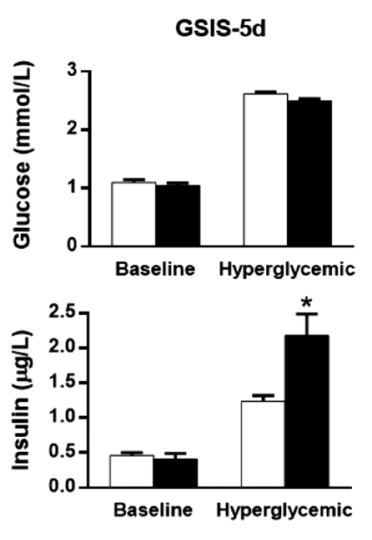

Figure 2

Persistent enhancement of GSIS in NE fetuses. Plasma glucose and insulin concentrations are presented for the three GSIS studies, which are labeled above the graphs: before (GSIS-pre), 1 day after (GSIS-1d) and 5 days after (GSIS-5d) the chronic infusion. Baseline and hyperglycemic steady state period means for control $(n=6-7)$ and NE fetuses $(n=8)$ were analyzed within each GSIS study. Differences $(P<0.05)$ between control and NE fetuses within the period are identified $(*)$. 
polypeptide (1:500; Dako). Immune complexes were detected with affinity-purified secondary antiserum conjugated to Cy2 (rabbit), Texas Red (mouse), or 7-amino-4-methylcoumarin-3-acetic acid (AMCA, guinea pig; Jackson ImmunoResearch Laboratories) diluted 1:500 in PBS with 1\% BSA. Fluorescent staining was visualized on a Leica DM5500 microscope system and digitally captured with a Spot Pursuit 4 Megapixel
CCD camera (Diagnostic Instruments, Sterling Heights, MI, USA). Morphometric analysis was performed with ImagePro 6.0 software (Media Cybernetics, Silver Spring, MD, USA). Positive areas were determined from 25 fields of view $\left(F O V=0.39 \mathrm{~mm}^{2}\right)$ on two pancreas sections per animal separated by $\geq 120 \mu \mathrm{m}$ intervals (total area $=19.5 \mathrm{~mm}^{2}$; coefficient of variation between sections $=10.7 \%)$.

Table 1 Glucose infusion, blood gas, lactate and norepinephrine concentrations during GSIS studies.

\begin{tabular}{|c|c|c|c|c|c|c|}
\hline Study & Parameter & Period & Control $(n=7)$ & NE $(n=8)$ & $\begin{array}{c}P \text { Value } \\
\text { treatment }\end{array}$ & $\begin{array}{l}P \text { Value } \\
\text { period }\end{array}$ \\
\hline \multirow[t]{15}{*}{ GSIS-pre } & Glucose infusion (mmol/h) & Hyperglycemia & $11.0 \pm 1.2$ & $12.5 \pm 0.7$ & NS & \\
\hline & $\mathrm{pH}$ & Baseline & $7.33 \pm 0.01$ & $7.34 \pm 0.01$ & NS & $<0.01$ \\
\hline & & Hyperglycemia & $7.31 \pm 0.01$ & $7.32 \pm 0.01$ & & \\
\hline & $\mathrm{PaO}_{2}(\mathrm{mmHg})$ & Baseline & $21.3 \pm 0.3$ & $20.9 \pm 0.6$ & NS & $<0.05$ \\
\hline & & Hyperglycemia & $20.5 \pm 0.3$ & $20.9 \pm 0.5$ & & \\
\hline & $\mathrm{PaCO}_{2}(\mathrm{mmHg})$ & Baseline & $48.8 \pm 0.5$ & $49.4 \pm 0.4$ & NS & $<0.01$ \\
\hline & & Hyperglycemia & $50.3 \pm 0.6$ & $50.7 \pm 0.5$ & & \\
\hline & Oxygen content (mmol/L) & Baseline & $3.7 \pm 0.1$ & $3.7 \pm 0.1$ & NS & $<0.05$ \\
\hline & & Hyperglycemia & $3.3 \pm 0.1$ & $3.5 \pm 0.1$ & & \\
\hline & Hematocrit (\%) & Baseline & $33.3 \pm 0.6$ & $34.6 \pm 0.4$ & NS & $<0.01$ \\
\hline & & Hyperglycemia & $32.9 \pm 0.6$ & $34.3 \pm 0.3$ & & \\
\hline & Lactate (mmol/L) & Baseline & $2.03 \pm 0.09$ & $1.94 \pm 0.08$ & NS & $<0.01$ \\
\hline & & Hyperglycemia & $2.50 \pm 0.09$ & $2.33 \pm 0.08$ & & \\
\hline & $\mathrm{NE}$ (ng/mL) & Baseline & $0.50 \pm 0.08$ & $0.53 \pm 0.08$ & NS & $<0.05$ \\
\hline & & Hyperglycemia & $0.61 \pm 0.10$ & $0.72 \pm 0.13$ & & \\
\hline \multirow[t]{15}{*}{ GSIS-1d } & Glucose infusion (mmol/h) & Hyperglycemia & $14.2 \pm 0.9$ & $11.8 \pm 1.1$ & NS & \\
\hline & $\mathrm{pH}$ & Baseline & $7.32 \pm 0.01$ & $7.32 \pm 0.01$ & NS & $<0.01$ \\
\hline & & Hyperglycemia & $7.30 \pm 0.01$ & $7.30 \pm 0.01$ & & \\
\hline & $\mathrm{PaO}_{2}(\mathrm{mmHg})$ & Baseline & $20.1 \pm 0.5$ & $26.0 \pm 0.6$ & $<0.01$ & $<0.05$ \\
\hline & & Hyperglycemia & $19.9 \pm 0.5$ & $24.7 \pm 0.8$ & & \\
\hline & $\mathrm{PaCO}_{2}(\mathrm{mmHg})$ & Baseline & $50.5 \pm 0.4$ & $46.1 \pm 0.6$ & $<0.01$ & $<0.01$ \\
\hline & & Hyperglycemia & $51.4 \pm 0.5$ & $47.2 \pm 0.7$ & & \\
\hline & Oxygen content (mmol/L) & Baseline & $3.2 \pm 0.2$ & $4.2 \pm 0.1$ & $<0.05$ & $<0.01$ \\
\hline & & Hyperglycemia & $3.0 \pm 0.1$ & $3.8 \pm 0.1$ & & \\
\hline & Hematocrit (\%) & Baseline & $34.0 \pm 1.0$ & $32.3 \pm 0.4$ & NS & $<0.01$ \\
\hline & & Hyperglycemia & $33.5 \pm 0.8$ & $31.8 \pm 0.5$ & & \\
\hline & Lactate (mmol/L) & Baseline & $2.12 \pm 0.13$ & $1.33 \pm 0.07$ & $<0.01$ & $<0.01$ \\
\hline & & Hyperglycemia & $2.66 \pm 0.13$ & $1.78 \pm 0.09$ & & \\
\hline & NE (ng/mL) & Baseline & $0.59 \pm 0.06$ & $3.11 \pm 0.56$ & $<0.01$ & NS \\
\hline & & Hyperglycemia & $0.62 \pm 0.07$ & $3.55 \pm 0.65$ & & \\
\hline \multirow[t]{15}{*}{ GSIS-5d } & Glucose infusion (mmol/h) & Hyperglycemia & $14.3 \pm 1.1$ & $13.7 \pm 0.8$ & NS & \\
\hline & $\mathrm{pH}$ & Baseline & $7.32 \pm 0.01$ & $7.34 \pm 0.01$ & NS & $<0.01$ \\
\hline & & Hyperglycemia & $7.30 \pm 0.01$ & $7.31 \pm 0.01$ & & \\
\hline & $\mathrm{PaO}_{2}(\mathrm{mmHg})$ & Baseline & $20.3 \pm 0.6$ & $20.7 \pm 0.4$ & NS & $<0.05$ \\
\hline & & Hyperglycemia & $19.3 \pm 0.5$ & $20.3 \pm 0.5$ & & \\
\hline & $\mathrm{PaCO}_{2}(\mathrm{mmHg})$ & Baseline & $50.7 \pm 0.5$ & $51.4 \pm 0.3$ & NS & $<0.01$ \\
\hline & & Hyperglycemia & $51.6 \pm 0.6$ & $52.7 \pm 0.4$ & & \\
\hline & Oxygen content (mmol/L) & Baseline & $2.8 \pm 0.1$ & $3.1 \pm 0.1$ & NS & $<0.01$ \\
\hline & & Hyperglycemia & $2.5 \pm 0.1$ & $2.9 \pm 0.1$ & & \\
\hline & Hematocrit (\%) & Baseline & $31.3 \pm 1.0$ & $30.9 \pm 0.6$ & NS & $<0.01$ \\
\hline & & Hyperglycemia & $30.9 \pm 0.9$ & $30.5 \pm 0.6$ & & \\
\hline & Lactate (mmol/L) & Baseline & $2.37 \pm 0.15$ & $2.04 \pm 0.13$ & NS & $<0.01$ \\
\hline & & Hyperglycemia & $3.11 \pm 0.20$ & $2.66 \pm 0.10$ & & \\
\hline & NE (pg/mL) & Baseline & $0.56 \pm 0.11$ & $1.60 \pm 0.17$ & $<0.05$ & NS \\
\hline & & Hyperglycemia & $0.67 \pm 0.09$ & $1.50 \pm 0.23$ & & \\
\hline
\end{tabular}

No significant interactions between treatment and period were identified. Values are means \pm S.E.M. NS, not significant.

๑) 2017 Society for Endocrinology Printed in Great Britain 


\section{Statistical analysis}

Differences between treatments (control and NE) for animal weights, daily intake, islet $\mathrm{IC}_{50}$ and pancreas morphology were analyzed by one-way ANOVA (treatments) using the general linear means procedure (SAS 9.4, SAS Institute Inc., Cary, NC, USA), and differences were determined with Student's $t$ test. Repeated measurement for biochemical, hematological and hormone from daily samples, GSIS studies, GPAIS studies and ex vivo islet experiments were analyzed by ANOVA using Proc MIXED with fetus as the random effect (SAS 9.4). Main effects within GSIS studies were treatment, period and their interaction. Main effects for GPAIS within treatment were study, sample time and their interaction. When the overall ANOVA was significant $(\alpha=0.05)$, individual means were separated with a least significant difference test. Data are presented as the mean \pm S.E.M.

\section{Results}

\section{Animal weights and daily intake}

Maternal body weights were not different between control $(56.8 \pm 3.9 \mathrm{~kg})$ and NE ewes $(52.8 \pm 3.3 \mathrm{~kg})$. During the treatment, average daily feed and water intake were similar in control $(1.8 \pm 0.1 \mathrm{~kg}$ and $7.5 \pm 0.9 \mathrm{~L})$ and $\mathrm{NE}$ ewes $(1.9 \pm 0.1 \mathrm{~kg}$ and $7.2 \pm 0.6 \mathrm{~L})$. Fetal age at necropsy was similar in control ( $140 \pm 1 \mathrm{dGA}, 3$ male and 4 female) and NE fetuses (141 $\pm 1 \mathrm{dGA}, 7$ male and 1 female). Fetal weight was not different between control $(3.96 \pm 0.23 \mathrm{~kg})$ and NE fetuses $(4.02 \pm 0.20 \mathrm{~kg})$.

\section{Daily fetal blood parameters}

Prior to chronic infusions, fetal plasma glucose, insulin, NE, and blood $\mathrm{PaO}_{2}$ were not different between experimental groups (Fig. 1). During the 7-day infusion, average $\mathrm{NE}$ concentrations were higher $(9.26 \pm 0.87 \mathrm{ng} / \mathrm{mL}$ vs $0.88 \pm 0.11 \mathrm{ng} / \mathrm{mL}, P<0.01)$, insulin concentrations were lower in NE fetuses compared to controls $(0.12 \pm 0.01 \mu \mathrm{g} / \mathrm{L}$ vs $0.43 \pm 0.02 \mu \mathrm{g} / \mathrm{L}, P<0.01)$ and glucose concentrations were not different. NE fetuses also had higher blood $\mathrm{PaO}_{2}$ than controls $(27.3 \pm 0.5 \mathrm{mmHg}$ vs $20.8 \pm 0.3 \mathrm{mmHg}$, $P<0.01)$. There was no treatment by day interaction for $\mathrm{NE}$, glucose, insulin or $\mathrm{PaO}_{2}$ during this period.

During the 5 days after infusion, average plasma NE concentrations $(2.46 \pm 0.41 \mathrm{ng} / \mathrm{mL}$ vs $0.61 \pm 0.07 \mathrm{ng} / \mathrm{mL}$; $P<0.01)$ and blood $\mathrm{PaO}_{2} \quad(23.0 \pm 0.4 \mathrm{mmHg} \quad$ vs $20.1 \pm 0.4 \mathrm{mmHg}, \quad P<0.01)$ remained elevated in $\mathrm{NE}$ fetuses compared to controls, respectively, but both measurements were lower $(P<0.05)$ after infusion than during infusion (Fig. 1). Glucose and insulin concentrations were not different between treatments after the chronic infusion ended. There was no treatment by day interaction for any of these variables.

\section{Fetal glucose-stimulated insulin secretion}

By design, glucose concentrations were increased to $2.5 \pm 0.1 \mathrm{mmol} / \mathrm{L}(P<0.01)$ from baseline during the
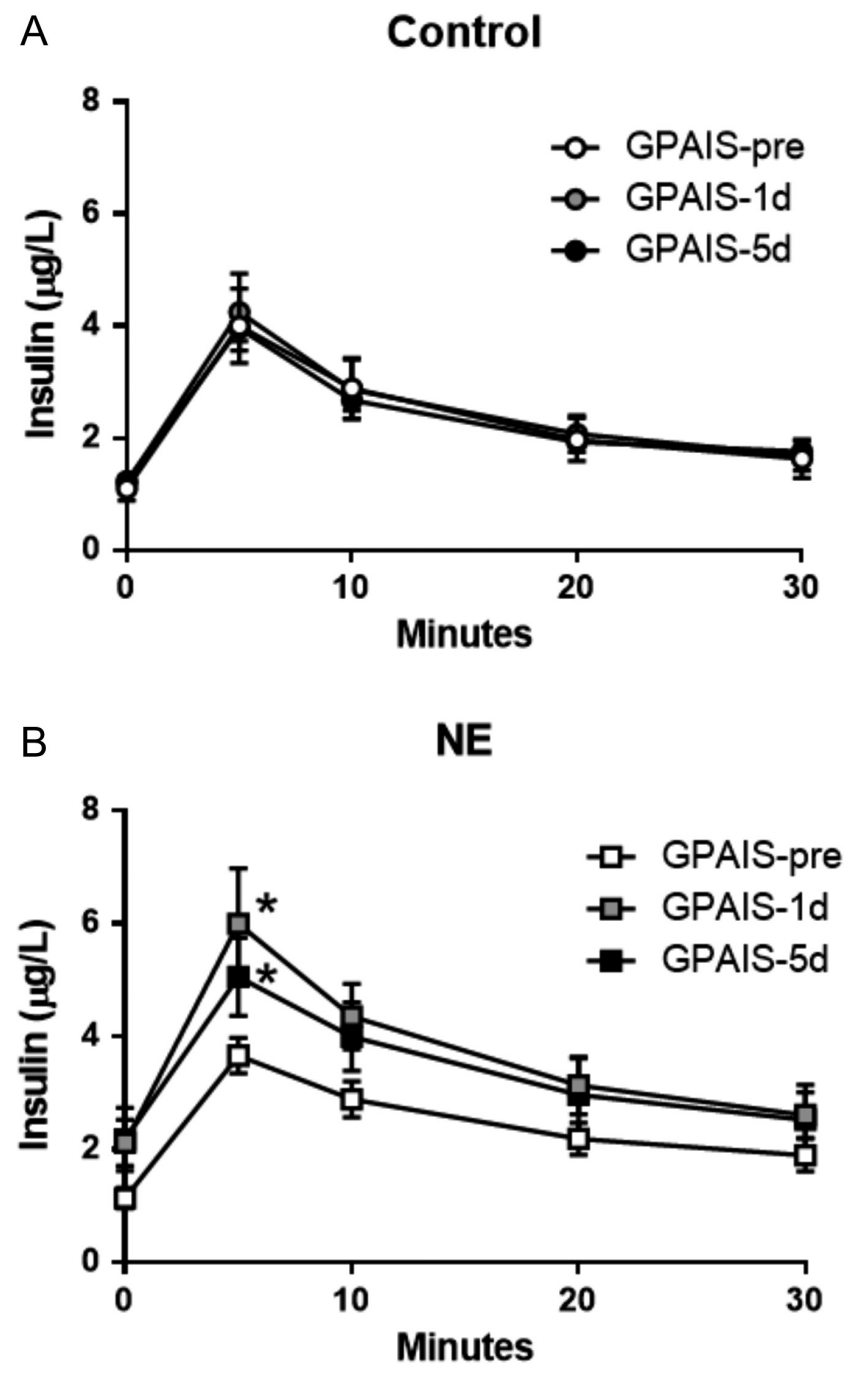

Figure 3

Persistent enhancement of GPAIS in NE fetuses. Insulin concentrations are presented for the GPAIS studies in control (A, $n=6-7)$ and NE fetuses (B, $n=8$ ). The arginine bolus is administered at time 0 . GPAIS studies were conducted before (GPAIS-pre), 1 day after (GPAIS-1d) and 5 days after (GPAIS-5d) the chronic treatment. There was no study by time interaction. Study differences $\left({ }^{*} P<0.05\right)$ for the average insulin concentration were observed in the NE fetuses but not controls.

Published by Bioscientifica Ltd 
hyperglycemic period of all three GSIS studies (Fig. 2). Baseline and hyperglycemic glucose concentrations were not different between treatments in any GSIS studies. The glucose infusion rate used to maintain the hyperglycemic clamp was also not different between treatment groups (Table 1).

In the GSIS pre-study, baseline insulin concentrations at either period were not different between treatments and increased $(P<0.001)$ with hyperglycemia similarly in both treatment groups (Fig. 2). Baseline insulin concentrations also were not different between NE and control fetuses in GSIS-1d or GSIS-5d studies, but insulin concentrations during the hyperglycemic periods were greater $(P<0.05)$ in $\mathrm{NE}$ fetuses than controls in both studies. Insulin secretion responsiveness (difference between baseline and hyperglycemic insulin concentrations) was not different among three GSIS studies in control fetuses. In NE fetuses, however, insulin secretion responsiveness was greater $(P<0.01)$ in GSIS-1d $(1.46 \pm 0.36 \mu \mathrm{g} / \mathrm{L})$ and GSIS-5d $(1.77 \pm 0.44 \mu \mathrm{g} / \mathrm{L})$ compared to GSIS-pre $(0.66 \pm 0.12 \mu \mathrm{g} / \mathrm{L})$.

Blood gas, $\mathrm{pH}$, hematocrit, plasma lactate and plasma NE were not different between treatments in GSIS-pre, although differences in period means were found; there was no treatment by period interaction (Table 1). In GSIS-1d, NE fetuses had greater $\mathrm{PaO}_{2}$ $(25.4 \pm 0.5 \mathrm{mmHg}$ vs $20.0 \pm 0.3 \mathrm{mmHg}, P<0.01)$, blood oxygen content $(4.0 \pm 0.1 \mathrm{mmol} / \mathrm{L}$ vs $3.1 \pm 0.1 \mathrm{mmol} / \mathrm{L}$, $P<0.05)$ and NE concentrations $(3.33 \pm 0.42 \mathrm{ng} / \mathrm{mL}$ vs $0.61 \pm 0.05 \mathrm{ng} / \mathrm{mL}, P<0.01)$ than controls, respectively. The blood $\mathrm{PaCO}_{2}$ values were lower in $\mathrm{NE}$ fetuses than controls $(46.7 \pm 0.5 \mathrm{mmHg}$ vs $51.0 \pm 0.3 \mathrm{mmHg}$, $P<0.01$ ), whereas $\mathrm{pH}$, hematocrit and lactate were not different. In GSIS-5d, NE remained greater than controls $\quad(1.54 \pm 0.14 \mathrm{ng} / \mathrm{mL}$ vs $0.62 \pm 0.07 \mathrm{ng} / \mathrm{mL}$, $P<0.05$; Table 1).

\section{Fetal glucose-potentiated arginine-induced insulin secretion}

GPAIS was enhanced in NE fetuses after infusion but controls were unaffected (Fig. 3). Average GPAIS insulin concentrations in NE fetuses were greater $(P<0.01)$ in GPAIS- $1 \mathrm{~d}(4.02 \pm 0.39 \mu \mathrm{g} / \mathrm{L})$ and GPAIS- $5 \mathrm{~d}(3.64 \pm 0.35 \mu \mathrm{g} / \mathrm{L})$ compared to GPIAS-pre $(2.66 \pm 0.19 \mu \mathrm{g} / \mathrm{L})$, which was similar to all three control GPAIS studies.

\section{Islet responsiveness}

Insulin secretion rates from isolated fetal sheep islets were measured in the presence of $11.1 \mathrm{mmol} / \mathrm{L}$ glucose and various NE concentrations (Fig. 4A). Maximum glucosestimulated insulin secretion was greater in $\mathrm{NE}$ islets than control islets $(2.20 \pm 0.27 \mathrm{ng} / \mathrm{islet} / \mathrm{h}$ vs $1.38 \pm 0.24 \mathrm{ng} /$ islet/h, $P<0.05)$. Minimum insulin secretion rates with $\mathrm{NE}$ inhibition were not different between NE $(0.74 \pm 0.18 \mathrm{ng} /$ islet $/ \mathrm{h})$ and control islets $(0.68 \pm 0.15 \mathrm{ng} / \mathrm{islet} / \mathrm{h})$, and these rates were also not different from incubations with no glucose. In islet incubations with $30 \mathrm{mmol} / \mathrm{L} \mathrm{KCl}$, insulin secretion rates were greater $(P<0.05)$ than other conditions but not different between treatments (NE, $8.84 \pm 1.47 \mathrm{ng} / \mathrm{islet} / \mathrm{h}$ vs control, $5.66 \pm 1.91 \mathrm{ng} / \mathrm{islet} / \mathrm{h})$. The $\mathrm{IC}_{50}$ concentration was greater $(P<0.05)$ for $\mathrm{NE}$ than that for control islets (Fig. 4B). Insulin contents of isolated islets were not different between NE and control fetuses (Fig. 4C).

Cytosolic calcium concentrations at $1.1 \mathrm{mmol} / \mathrm{L}$ glucose were not different between NE and control islets (340/380 ratio of $0.66 \pm 0.01$ in $\mathrm{NE}$ and $0.67 \pm 0.06$ in controls). High glucose concentrations and $30 \mathrm{mmol} / \mathrm{L}$ $\mathrm{KCl}$ increased intracellular calcium, but means were not different between treatments $(0.71 \pm 0.01$ in NE vs $0.73 \pm 0.07$ in control for high glucose, and $1.24 \pm 0.08$ in $\mathrm{NE}$ vs $1.46 \pm 0.20$ in control for $\mathrm{KCl}$ ).
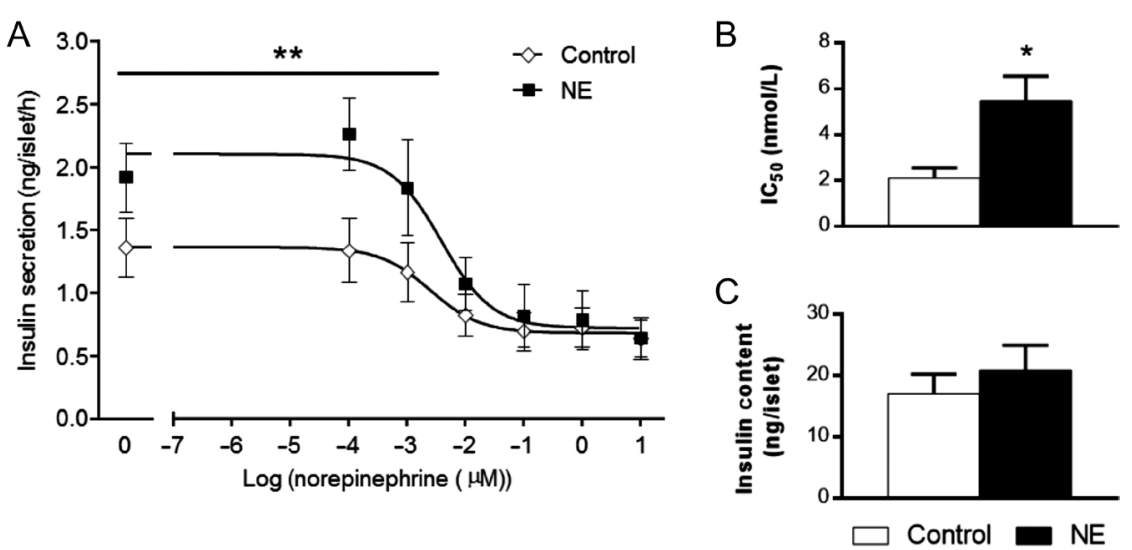

Figure 4

Enhanced glucose-stimulated insulin secretion in NE islets. Pancreatic islets were isolated from control and NE fetuses ( $n=6$ animals/treatment). (A) Insulin secretion rates were measured in static incubations that contain $11.1 \mathrm{mmol} / \mathrm{L}$ glucose and various NE concentrations that ranged from 0 to $10 \mu \mathrm{mol} / \mathrm{L}$ ( $y$-axis). The bar with asterisks indicate that the maximum insulin secretion rate was significantly different $(P<0.01)$ between control and NE islets. (B) The half maximal inhibitory concentration $\left(\mathrm{IC}_{50}\right)$ was calculated for each treatment. Values represent means \pm S.E.M., and the asterisks indicate a difference $(P<0.05)$ between treatment groups. (C) Islet insulin contents were not different between treatments. (c) 2017 Society for Endocrinology Printed in Great Britain 
Table 2 Endocrine pancreas morphometry.

\begin{tabular}{|c|c|c|}
\hline & Control $(n=7)$ & NE $(n=6)$ \\
\hline$\beta$-cell area $(\%)$ & $2.22 \pm 0.43$ & $2.04 \pm 0.26$ \\
\hline$\alpha$-cell area $(\%)$ & $1.48 \pm 0.19$ & $1.67 \pm 0.28$ \\
\hline$\delta$ - and PP-cell area (\%) & $0.97 \pm 0.10$ & $0.98 \pm 0.17$ \\
\hline Total endocrine area (\%) & $4.66 \pm 0.67$ & $4.69 \pm 0.61$ \\
\hline
\end{tabular}

Values are means \pm S.E.M.

$\mathrm{PP}$, pancreatic polypeptide.

\section{Pancreatic endocrine cell area}

There were no differences in the total area staining positive for insulin ( $\beta$-cells), glucagon ( $\alpha$-cells) or the combination of somatostatin ( $\delta$-cells) and pancreatic polypeptide cells (F-cells) between treatments (Table 2).

\section{Discussion}

Fetal stress associated with placental dysfunction chronically elevates catecholamines (Greenough et al. 1990, Okamura et al. 1990). In this study, we demonstrate that sustained exposure to elevated NE directly produces lasting adaptations in fetal $\beta$-cells. The compensatory increase in insulin secretion responsiveness to glucose and arginine was still observed five days after cessation of the NE infusion. Furthermore, we confirmed enhanced insulin secretion to glucose was intrinsic to the islets after isolation. Although the increased $\beta$-cell responsiveness to glucose and arginine was not explained by differences in $\beta$-cell mass, insulin content or intracellular calcium signaling, the $\beta$-cells remained desensitized to adrenergic stimulation, which supports previous findings that show lower expression of adrenergic receptors and signaling molecules (Chen et al. 2014). Previously, IUGR fetuses with elevated catecholamines exhibited improved $\beta$-cell responsiveness during adrenergic blockade, indicating adaptive programming effects from chronic adrenergic stimulation are present (Leos et al. 2010, Macko et al. 2013). In these previous studies, we found the compensatory increase in insulin secretion responsiveness immediately after reducing the adrenergic stimulation, whereas here we show that the enhancement was maintained for five days after removal of elevated adrenergic stimulation indicating that the effects were programmed.

Enhanced insulin secretion responsiveness to secretagogues and adrenergic desensitization represent two functional adaptations in the $\beta$-cell that persisted well beyond the end of NE infusion. These findings expand our previous work where we observed a compensatory increase in insulin secretion three hours after terminating the NE infusion and also showed lower expression of $\alpha_{2}$-ARs and $G_{\alpha i-2}$ protein in fetal sheep islets. It is likely that these two effects are interrelated because recent genetic studies reveal that overexpression of $\alpha_{2 \mathrm{~A}}$-AR causes impaired docking and exocytosis of insulin granules (Rosengren et al. 2010, 2012, Straub $\&$ Sharp 2012). However, this tonic inhibition of insulin release was alleviated with $\alpha_{2}$-AR antagonists (Rosengren et al. 2010, Yang et al. 2012). Conversely, $\alpha_{2 \mathrm{~A}}$-AR-deficient mice not only lack inhibitory actions in pancreatic $\beta$-cell but also are hyperinsulinemic and hypoglycemic (Fagerholm et al. 2004, Savontaus et al. 2008). The $\alpha_{2}$-ARs desensitization in pancreatic $\beta$-cells found in the present study may, in part, explain the compensatory increase in $\beta$-cell responsiveness after cessation of hypercatecholaminemia because of the loss of tonic inhibition by adrenergic receptors.

Alternative mechanisms for enhanced GSIS and GPAIS responsiveness in the NE fetus may include increased metabolic coupling to oxidative phosphorylation or regulation of secretory granule exocytosis. We have previously shown that uncoupling protein 2 (UCP2) mRNA expression is reduced in NE islets after acute recovery overnight culture in vivo (Chen et al. 2014). In $\beta$-cells, UCP2 is a negative regulator of insulin secretion because it decreases the proton-motive force in the inner mitochondria membrane to circumvent ATP synthesis (Zhang et al. 2001, Affourtit \& Brand 2006, 2008). Conversely, a reduction of UCP2 as identified in islets of NE fetuses enhances insulin secretion (Zhang et al. 2006, Robson-Doucette et al. 2011). The reduction in UCP2 expression in NE islets may be a direct effect of adrenergic stimulation or an indirect effect because adrenergic stimulation decreases rates of glucose metabolism (Laychock \& Bilgin 1987, Laychock 1989, Dalgaard 2012). Transcriptome expression analysis by high-throughput RNA sequencing of NE islets revealed significant increases in chloride channel calcium-activated family member 1 (CLCA1) and FXYD domain containing ion transport regulator 2 and significant decreases in solute carrier family 9 member A2 $\left(\mathrm{Na}^{+} / \mathrm{H}^{+}\right.$exchanger 2$)$ and inositol 1,4,5-trisphosphate receptor type 2 in NE islets compared to controls after the acute recovery (unpublished data). Although additional work is necessary to determine the role of these ion channels in the NE islets, there is evidence that chloride flux across the $\beta$-cell membrane can modulate exocytotic capacity and alter depolarization kinetics (Barg et al. 1999, 2001, Thevenod 2002).

Published by Bioscientifica Ltd. 
In our previous study using chronic 7-day NE infusion, we observed hyperglycemia and increased arterial blood oxygen tension in NE fetuses during the treatment. In the present study, we maintained fetal glucose concentrations at normal values to eliminate the confounding influence of chronic hyperglycemia, which was previously demonstrated to negatively influence insulin secretion (Carver et al. 1995, Green et al. 2012). Here, we confirm that the NE-induced compensation in fetal sheep islets is independent of the fetal glucose concentrations. Moreover, when we compare the NE fetal cohorts and the PI-IUGR fetal sheep cohort that is hypoglycemic (Leos et al. 2010, Macko et al. 2013), we can exclude an influence of fetal glucose concentrations for the compensatory enhancement in $\beta$-cell function after chronic NE exposure because it is present in fetuses with hypoglycemic, hyperglycemic and euglycemic conditions. Similarly, oxygen tension is not expected to affect these results because they persist in models with different fetal oxygenation. Acutely, in normal sheep fetuses, higher blood $\mathrm{PaO}_{2}$ did not augment GSIS (Jackson et al. 2000), and when placental insufficiency-induced IUGR fetuses were oxygenated to normal levels from hypoxemia, insulin secretion was enhanced independently of norepinephrine concentrations (Macko et al. 2016).

Plasma NE concentrations of NE fetuses remained 5.3-fold and 2.5-fold higher than controls at one and five days after terminating NE infusion, respectively. Chronic NE exposure or physiological hypoxic challenges in fetal sheep and lambs inhibit catecholamine clearance rates in the placenta and lung, which partially explain the prolonged elevation (Chappell et al. 1991, Bzoskie et al. $1995,1997)$. Also, if $\alpha_{2}$-ARs on the adrenal chromaffin cells were desensitized, increased rates of NE synthesis would be expected because the adrenal glands possess short feedback inhibition similar to sympathetic neurons (Brede et al. 2003, Moura et al. 2006). Despite the elevation of NE, NE fetuses still had significantly higher $\beta$-cell responsiveness, indicating that the new levels of catecholamines are below effective concentrations to inhibit insulin secretion.

Persistence in enhanced insulin secretion responsiveness resulting from chronically elevated NE in utero begins to explain the common occurrence for transient hyperinsulinemic hypoglycemia seen in infants born small-for-gestational age or with perinatal stress (Collins et al. 1990, Duvanel et al. 1999, Stanley et al. 2015). The baseline insulin and glucose concentrations in NE fetuses are equivalent to controls, but glucose concentrations will increase after delivery. If the increased $\beta$-cell sensitivity continues postnatally, it is anticipated that hyperinsulinemia will pursue and lower neonatal glucose concentrations. Hyperinsulinemia and hypoglycemia will be exacerbated by adrenergic receptor desensitization because counter regulatory mechanisms for glucose homeostasis will be reduced (Hawdon et al. 1993, Chen et al. 2010, Rozance \& Hay 2010). Although management of asymptomatic hypoglycemia is controversial, reoccurring episodes are associated with poor neurodevelopment and growth deficits (Duvanel et al. 1999, Rozance \& Hay 2016). Therefore, although the symptoms may resolve, there are potential long-term consequences to transient hyperinsulinemic hypoglycemia in neonate that may result from chronically elevated NE.

In conclusion, chronic elevation of NE concentration, nothyperglycemia, producesa compensatoryenhancement in $\beta$-cell responsiveness to insulin secretagogues after terminating the NE infusion in fetal sheep. Improved insulin secretion was intrinsic to pancreatic islets, which maintained $\alpha_{2}$-AR desensitization six days after termination of NE infusion, which may contribute to the manifestation of persistent adaptation in $\beta$-cells. Although previous studies in PI-IUGR fetuses and lambs support peripheral adrenergic receptor desensitization that impairs the ability of catecholamines to mobilize free fatty acids (Chen et al. 2010, Yates et al. 2012b, 2016), this is the first study to describe programming effects from NE in $\beta$-cells. Importantly, the $\beta$-cell dysfunction created by $\mathrm{NE}$ infusion begins to explain the potential variability in small-for-gestational age infants because sustained exposure to high catecholamine levels is found in IUGR infants. The enhanced $\beta$-cell responsiveness induced by chronic high catecholamine concentrations in the fetus will create an imbalance in the insulin disposition index that may impair the maturation of glucose homeostasis.

\section{Declaration of interest}

The authors declare that there is no conflict of interest that could be perceived as prejudicing the impartiality of the research reported.

\section{Funding}

This work was supported by the National Institute of Health R01DK084842 (S W Limesand, Principal Investigator). X Chen was supported by National Natural Science Foundation of China (NSFC, Grant No. 31602021), Chongqing Science and Technology Commission, Chongqing, China (Grant No. CSTC2014JCYJA80036) and Southwest University (Grant No. 20140090). D T Yates and A R Macko were supported by T32HL7249 (J Burt, Principle Investigator). The content of this article is solely the responsibility of the authors and does not necessarily represent the official views of the funding agencies.

Published by Bioscientifica Ltd 


\section{Acknowledgements}

The authors thank Miranda J Anderson, Craig S Weber and Mandie M Dunham for technical assistance.

\section{References}

Affourtit C \& Brand MD 2006 Stronger control of ATP/ADP by proton leak in pancreatic beta-cells than skeletal muscle mitochondria. Biochemical Journal 393 151-159. (doi:10.1042/BJ20051280)

Affourtit C \& Brand MD 2008 Uncoupling protein-2 contributes significantly to high mitochondrial proton leak in INS-1E insulinoma cells and attenuates glucose-stimulated insulin secretion. Biochemical Journal 409 199-204. (doi:10.1042/BJ20070954)

Ananth CV \& Friedman AM 2014 Ischemic placental disease and risks of perinatal mortality and morbidity and neurodevelopmental outcomes. Seminars in Perinatology 38 151-158. (doi:10.1053/j. semperi.2014.03.007)

Ananth CV \& Vintzileos AM 2006 Maternal-fetal conditions necessitating a medical intervention resulting in preterm birth. American Journal of Obstetrics and Gynecology 195 1557-1563. (doi:10.1016/j. ajog.2006.05.021)

Apatu RS \& Barnes RJ 1991 Release of glucose from the liver of fetal and postnatal sheep by portal vein infusion of catecholamines or glucagon. Journal of Physiology 436 449-468. (doi:10.1113/ jphysiol.1991.sp018560)

Barg S, Renstrom E, Berggren PO, Bertorello A, Bokvist K, Braun M, Eliasson L, Holmes WE, Kohler M, Rorsman P et al. 1999 The stimulatory action of tolbutamide on Ca2+-dependent exocytosis in pancreatic beta cells is mediated by a $65-\mathrm{kDa}$ mdr-like P-glycoprotein. PNAS 96 5539-5544. (doi:10.1073/pnas.96.10.5539)

Barg S, Huang P, Eliasson L, Nelson DJ, Obermuller S, Rorsman P, Thevenod F \& Renstrom E 2001 Priming of insulin granules for exocytosis by granular $\mathrm{Cl}(-)$ uptake and acidification. Journal of Cell Science 114 2145-2154.

Bassett JM \& Hanson C 1998 Catecholamines inhibit growth in fetal sheep in the absence of hypoxemia. American Journal of Physiology 274 R1536-R1545.

Brede M, Nagy G, Philipp M, Sorensen JB, Lohse MJ \& Hein L 2003 Differential control of adrenal and sympathetic catecholamine release by alpha 2-adrenoceptor subtypes. Molecular Endocrinology 17 1640-1646. (doi:10.1210/me.2003-0035)

Bzoskie L, Blount L, Kashiwai K, Tseng YT, Hay WW Jr \& Padbury JF 1995 Placental norepinephrine clearance: in vivo measurement and physiological role. American Journal of Physiology 269 E145-E149.

Bzoskie L, Blount L, Kashiwai K, Humme J \& Padbury JF 1997 The contribution of transporter-dependent uptake to fetal catecholamine clearance. Biology of the Neonate 71 102-110. (doi:10.1159/000244403)

Carver TD, Anderson SM, Aldoretta PA, Esler AL \& Hay WW Jr 1995 Glucose suppression of insulin secretion in chronically hyperglycemic fetal sheep. Pediatric Research 38 754-762. (doi:10.1203/00006450199511000-00020)

Chappell BA, Padbury JF, Habib DM, Martinez AM, Thio SL, Burnell EE \& Humme JA 1991 Pulmonary clearance of norepinephrine in lambs. Pediatric Research 29 93-97. (doi:10.1203/00006450-19910100000018)

Chen X, Fahy AL, Green AS, Anderson MJ, Rhoads RP \& Limesand SW 2010 beta2-Adrenergic receptor desensitization in perirenal adipose tissue in fetuses and lambs with placental insufficiency-induced intrauterine growth restriction. Journal of Physiology 588 3539-3549. (doi:10.1113/jphysiol.2010.192310)

Chen X, Green AS, Macko AR, Yates DT, Kelly AC \& Limesand SW 2014 Enhanced insulin secretion responsiveness and islet adrenergic desensitization after chronic norepinephrine suppression is discontinued in fetal sheep. American Journal of Physiology: Endocrinology and Metabolism 306 E58-E64. (doi:10.1152/ ajpcell.00249.2013)

Cole L, Anderson MJ, Antin PB \& Limesand SW 2009 One process for pancreatic b-cell coalescence into islets involves an epithelialmesenchymal transition. Journal of Endocrinology 203 19-31. (doi:10.1677/JOE-09-0072)

Collins JE, Leonard JV, Teale D, Marks V, Williams DM, Kennedy CR \& Hall MA 1990 Hyperinsulinaemic hypoglycaemia in small for dates babies. Archives of Disease in Childhood 65 1118-1120. (doi:10.1136/ adc.65.10.1118)

Dalgaard LT 2012 UCP2 mRNA expression is dependent on glucose metabolism in pancreatic islets. Biochemical and Biophysical Research Communications 417 495-500. (doi:10.1016/j.bbrc.2011.11.148)

Davis MA, Macko AR, Steyn LV, Anderson MJ \& Limesand SW 2015 Fetal adrenal demedullation lowers circulating norepinephrine and attenuates growth restriction but not reduction of endocrine cell mass in an ovine model of intrauterine growth restriction. Nutrients $\mathbf{7}$ 500-516. (doi:10.3390/nu7010500)

Duvanel CB, Fawer CL, Cotting J, Hohlfeld P \& Matthieu JM 1999 Long-term effects of neonatal hypoglycemia on brain growth and psychomotor development in small-for-gestational-age preterm infants. Journal of Pediatrics 134 492-498. (doi:10.1016/S00223476(99)70209-X)

Fagerholm V, Gronroos T, Marjamaki P, Viljanen T, Scheinin M \& Haaparanta M 2004 Altered glucose homeostasis in alpha2Aadrenoceptor knockout mice. European Journal of Pharmacology $\mathbf{5 0 5}$ 243-252. (doi:10.1016/j.ejphar.2004.10.023)

Green AS, Macko AR, Rozance PJ, Yates DT, Chen X, Hay WW Jr \& Limesand SW 2011 Characterization of glucose-insulin responsiveness and impact of fetal number and sex difference on insulin response in the sheep fetus. American Journal of Physiology: Endocrinology and Metabolism 300 E817-E823. (doi:10.1152/ajpendo.00572.2010)

Green AS, Chen X, Macko AR, Anderson MJ, Kelly AC, Hart NJ, Lynch RM \& Limesand SW 2012 Chronic pulsatile hyperglycemia reduces insulin secretion and increases accumulation of reactive oxygen species in fetal sheep islets. Journal of Endocrinology 212 327-342. (doi:10.1530/JOE-11-0300)

Greenough A, Nicolaides KH \& Lagercrantz H 1990 Human fetal sympathoadrenal responsiveness. Early Human Development 23 9-13. (doi:10.1016/0378-3782(90)90124-2)

Gresores A, Anderson S, Hood D, Zerbe GO \& Hay WW Jr 1997 Separate and joint effects of arginine and glucose on ovine fetal insulin secretion. American Journal of Physiology 272 E68-E73.

Hawdon JM, Weddell A, Aynsley-Green A \& Ward Platt MP 1993 Hormonal and metabolic response to hypoglycaemia in small for gestational age infants. Archives of Disease in Childhood 68 269-273. (doi:10.1136/adc.68.3_Spec_No.269)

Jackson BT, Piasecki GJ, Cohn HE \& Cohen WR 2000 Control of fetal insulin secretion. American Journal of Physiology: Regulatory Integrative and Comparative Physiology 279 R2179-R2188.

Laychock SG 1989 Prostaglandin E2 and alpha 2 adrenoceptor agonists inhibit the pentose phosphate shunt in pancreatic islets. Archives of Biochemistry and Biophysics 269 354-358. (doi:10.1016/00039861(89)90117-3)

Laychock SG \& Bilgin S 1987 Alpha 2-adrenergic inhibition of pancreatic islet glucose utilization is mediated by an inhibitory guanine nucleotide regulatory protein. FEBS Letters 218 7-10. (doi:10.1016/0014-5793(87)81007-4)

Leos RA, Anderson MJ, Chen X, Pugmire J, Anderson KA \& Limesand SW 2010 Chronic exposure to elevated norepinephrine suppresses insulin secretion in fetal sheep with placental insufficiency and intrauterine growth restriction. American Journal of Physiology: Endocrinology and Metabolism 298 E770-E778. (doi:10.1152/ajpendo.00494.2009)

Limesand SW \& Hay WW Jr 2003 Adaptation of ovine fetal pancreatic insulin secretion to chronic hypoglycaemia and euglycaemic http://joe.endocrinology-journals.org

DOI: $10.1530 / \mathrm{JOE}-16-0445$
(C) 2017 Society for Endocrinology Printed in Great Britain 
correction. Journal of Physiology 547 95-105. (doi:10.1113/ jphysiol.2002.026831)

Limesand SW, Rozance PJ, Zerbe GO, Hutton JC \& Hay WW Jr 2006 Attenuated insulin release and storage in fetal sheep pancreatic islets with intrauterine growth restriction. Endocrinology 147 1488-1497. (doi:10.1210/en.2005-0900)

Limesand SW, Rozance PJ, Macko AR, Anderson MJ, Kelly AC \& Hay WW Jr 2013 Reductions in insulin concentrations and beta-cell mass precede growth restriction in sheep fetuses with placental insufficiency. American Journal of Physiology: Endocrinology and Metabolism 304 E516-E523. (doi:10.1152/ajpendo.00435.2012)

Lynch RM, Weber CS, Nullmeyer KD, Moore ED \& Paul RJ 2008 Clearance of store-released $\mathrm{Ca} 2+$ by the $\mathrm{Na}+\mathrm{Ca} 2+$ exchanger is diminished in aortic smooth muscle from $\mathrm{Na}+\mathrm{K}+-\mathrm{ATPase}$ alpha 2-isoform gene-ablated mice. American Journal of Physiology: Heart and Circulatory Physiology 294 H1407-H1416. (doi:10.1152/ ajpcell.00399.2007)

Macko AR, Yates DT, Chen X, Green AS, Kelly AC, Brown LD \& Limesand SW 2013 Elevated plasma norepinephrine inhibits insulin secretion, but adrenergic blockade reveals enhanced b-cell responsiveness in an ovine model of placental insufficiency at 0.7 of gestation. Journal of Developmental Origins of Health and Disease 4 402-410. (doi:10.1017/ S2040174413000093)

Macko AR, Yates DT, Chen X, Shelton LA, Kelly AC, Davis MA, Camacho LE, Anderson MJ \& Limesand SW 2016 Adrenal demedullation and oxygen supplementation independently increase glucose-stimulated insulin concentrations in fetal sheep with intrauterine growth restriction. Endocrinology 157 2104-2115. (doi:10.1210/en.2015-1850)

Milley JR 1997 Ovine fetal metabolism during norepinephrine infusion. American Journal of Physiology 273 E336-E347.

Moura E, Afonso J, Hein L \& Vieira-Coelho MA 2006 Alpha2adrenoceptor subtypes involved in the regulation of catecholamine release from the adrenal medulla of mice. British Journal of Pharmacology 149 1049-1058. (doi:10.1038/sj.bjp.0706950)

Okamura K, Watanabe T, Tanigawara S, Endo H, Iwamoto M, Murotsuki J \& Yajima A 1990 Catecholamine levels and their correlation to blood gases in umbilical venous blood obtained by cordocentesis. Fetal Diagnosis and Therapy 5 147-152. (doi:10.1159/000263584)

Robson-Doucette CA, Sultan S, Allister EM, Wikstrom JD, Koshkin V, Bhattacharjee A, Prentice KJ, Sereda SB, Shirihai OS \& Wheeler MB 2011 Beta-cell uncoupling protein 2 regulates reactive oxygen species production, which influences both insulin and glucagon secretion. Diabetes 60 2710-2719. (doi:10.2337/db11-0132)

Rosengren AH, Jokubka R, Tojjar D, Granhall C, Hansson O, Li DQ, Nagaraj V, Reinbothe TM, Tuncel J, Eliasson L et al. 2010 Overexpression of alpha2A-adrenergic receptors contributes to type 2 diabetes. Science 327 217-220. (doi:10.1126/science.1176827)

Rosengren AH, Braun M, Mahdi T, Andersson SA, Travers ME, Shigeto M, Zhang E, Almgren P, Ladenvall C, Axelsson AS et al. 2012 Reduced insulin exocytosis in human pancreatic beta-cells with gene variants linked to type 2 diabetes. Diabetes 61 1726-1733. (doi:10.2337/db11-1516)

Rozance PJ \& Hay WW Jr 2010 Describing hypoglycemia - definition or operational threshold? Early Human Development 86 275-280. (doi:10.1016/j.earlhumdev.2010.05.002)

Rozance PJ \& Hay WW Jr 2016 New approaches to management of neonatal hypoglycemia. Maternal Health, Neonatology and Perinatology 2 3. (doi:10.1186/s40748-016-0031-z)

Rozance PJ, Limesand SW \& Hay WW Jr 2006 Decreased nutrient stimulated insulin secretion in chronically hypoglycemic late gestation fetal sheep is due to an intrinsic islet defect. American Journal of Physiology: Endocrinology and Metabolism 291 E404-E411. (doi:10.1152/ajpendo.00643.2005)

Rozance PJ, Anderson M, Martinez M, Fahy A, Macko AR, Kailey J, Seedorf GJ, Abman SH, Hay WW Jr \& Limesand SW 2015 Placental insufficiency decreases pancreatic vascularity and disrupts hepatocyte growth factor signaling in the pancreatic islet endothelial cell in fetal sheep. Diabetes 64 555-564. (doi:10.2337/db14-0462)

Savontaus E, Fagerholm V, Rahkonen O \& Scheinin M 2008 Reduced blood glucose levels, increased insulin levels and improved glucose tolerance in alpha2A-adrenoceptor knockout mice. European Journal of Pharmacology 578 359-364. (doi:10.1016/j.ejphar.2007.09.015)

Sperling MA, Ganguli S, Leslie N \& Landt K 1984 Fetal-perinatal catecholamine secretion: role in perinatal glucose homeostasis. American Journal of Physiology 247 E69-E74.

Stanley CA, Rozance PJ, Thornton PS, De Leon DD, Harris D, Haymond MW, Hussain K, Levitsky LL, Murad MH, Simmons RA et al. 2015 Re-evaluating 'transitional neonatal hypoglycemia': mechanism and implications for management. Journal of Pediatrics 166 1520-1525. (doi:10.1016/j.jpeds.2015.02.045)

Straub SG \& Sharp GW 2012 Evolving insights regarding mechanisms for the inhibition of insulin release by norepinephrine and heterotrimeric G proteins. American Journal of Physiology: Cell Physiology 302 C1687-C1698. (doi:10.1152/ajpcell.00282.2011)

Thevenod F 2002 Ion channels in secretory granules of the pancreas and their role in exocytosis and release of secretory proteins. American Journal of Physiology: Cell Physiology 283 C651-C672. (doi:10.1152/ ajpcell.00600.2001)

Yang J, Dolinger M, Ritaccio G, Mazurkiewicz J, Conti D, Zhu X \& Huang Y 2012 Leucine stimulates insulin secretion via down-regulation of surface expression of adrenergic alpha2A receptor through the mTOR (mammalian target of rapamycin) pathway: implication in new-onset diabetes in renal transplantation. Journal of Biological Chemistry 287 24795-24806. (doi:10.1074/jbc.M112.344259)

Yates DT, Macko AR, Chen X, Green AS, Kelly AC, Anderson MJ, Fowden AL \& Limesand SW 2012a Hypoxemia-induced catecholamine secretion from adrenal chromaffin cells inhibits glucose-stimulated hyperinsulinemia in fetal sheep. Journal of Physiology 590 5439-5447. (doi:10.1113/jphysiol.2012.237347)

Yates DT, Macko AR, Nearing M, Chen X, Rhoads RP \& Limesand SW $2012 b$ Developmental programming in response to intrauterine growth restriction impairs myoblast function and skeletal muscle metabolism. Journal of Pregnancy $\mathbf{2 0 1 2}$ article 631038 (doi:10.1155/2012/631038)

Yates DT, Cadaret CN, Beede KA, Riley HE, Macko AR, Anderson MJ Camacho LE \& Limesand SW 2016 Intrauterine growth-restricted sheep fetuses exhibit smaller hindlimb muscle fibers and lower proportions of insulin-sensitive Type I fibers near term. American Journal of Physiology: Regulatory Integrative and Comparative Physiology 310 R1020-R1029. (doi:10.1152/ajpregu.00528.2015)

Zhang CY, Baffy G, Perret P, Krauss S, Peroni O, Grujic D, Hagen T, VidalPuig AJ, Boss O, Kim YB et al. 2001 Uncoupling protein-2 negatively regulates insulin secretion and is a major link between obesity, beta cell dysfunction, and type 2 diabetes. Cell 105 745-755. (doi:10.1016/ S0092-8674(01)00378-6)

Zhang CY, Parton LE, Ye CP, Krauss S, Shen R, Lin CT, Porco JA Jr \& Lowell BB 2006 Genipin inhibits UCP2-mediated proton leak and acutely reverses obesity- and high glucose-induced beta cell dysfunction in isolated pancreatic islets. Cell Metabolism 3 417-427. (doi:10.1016/j.cmet.2006.04.010)

Received in final form 23 November 2016

Accepted 25 November 2016

Accepted Preprint published online 25 November 2016 http://joe.endocrinology-journals.org

DOI: 10.1530/JOE-16-0445
๑ 2017 Society for Endocrinology Printed in Great Britain 